\title{
MEMBANGUN SUMBER DAYA MANUSIA SEJAHTERA \\ (STUDI KASUS DI PROVINSI KALIMANTAN SELATAN)
}

Oleb: M. Ma'ruf Abdullab*

\section{Abstract}

The development of human resources is the kry to success of a state in terms of creating people prosperiry and social welfare. This condition can be empirically witnessed in a number of developed countries engaged in OECD (Organization for Economic and Co-operation for Development). In the creating of social prosperiry, a state is certainly faced by various problems, mainly in the sectors related to the improvement of the competitive qualiry of human resources, such as education, healtly, economy, and the power to purchase. The problem of developing buman resources should be placed as the main concern of the state. This attempt is aimed at establishing competitive advantage and producing excellent Indeks Pemahaman Manusia (IPM) or Human Development Index (HDI). With excellent and competitive buman resources, Indonesia will be able to create social welfare as that hoped by the founder father of the nation.

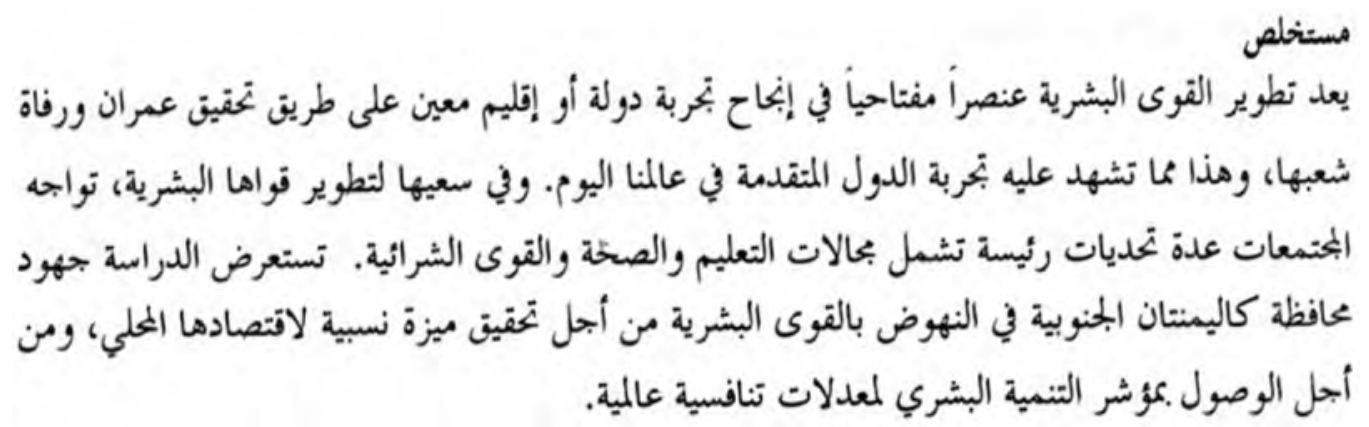

Keywords: SDM, Pendidikan, Kesehatan, Daya Beli, dan Kesejahteraan

Dosen Fakultas Syari’ah IAIN Antasari Banjarmasin. Email: yulizar_adriani@yahoo.com 


\section{A. Pendahuluan}

Untuk mewujudkan kemakmuran suatu negara atau daerah dan kesejahteraan bagi rakyatnya diperlukan suatu perencanaan pembangunan yang akurat, termasuk perencanaan pembangunan sumberdaya manusia (SDM) yang akan menangani pembangunan itu. Hal tersebut tersirat dalam makna firman Allah dalam Al-Qur'an berikut ini:

"Hai orang-orang yang beriman, bertaqwalah kepada Allah dan hendaklah setiap diri memperhatikan apa yang telah diperbuatnya untuk hari esok (akhirat) dan bertaqwalah kepada Allah, sesungguhnya Allah Maha Mengetahui apa yang kamu kerjakan" (QS. Al-Hasyr: 18)

Ayat ini mengandung konsep perencanaan yang harus disesuaikan dengan prediksi masa depan yang berangkat dari kondisi yang ada sekarang. Perencanaan adalah bagian penting dari sebuah kesuksesan. Jadi dapat dipastikan suatu kesuksesan dalam mencapai tujuan negara untuk mewujudkan kemakmuran dan kesejahteraan rakyat tidak dapat dicapai tanpa didasari dengan perencanaan.

\section{Kondisi Obyektif}

Perencanaan yang baik harus berangkat dari kondisi obyektif, kemudian dirancang dengan kondisi masa depan yang diinginkan. Dalam konteks tulisan ini perencanaan SDM yang dimaksud sesuai dengan format negara kesejahteraan yang akan memberikan kemakmuran bagi negara/daerah dan kesejahteraan bagi rakyatnya. Untuk keperluan ini (kasus di Provinsi Kalsel) ada 3 sektor utama yang perlu mendapat perhatian:

\subsection{Sektor Pendidikan}

Dalam rangka memperbaiki kualitas pendidikan ke depan ada sejumlah indikator pendidikan yang perlu dicermati. Khusus untuk Provinsi Kalimantan Selatan (lokasi studi kasus) indikator pendidikan yang dimaksud itu menunjukkan data sebagai berikut: ${ }^{1}$

1. Yang tidak/belum memiliki ijazah/STTB

$32,20 \%$

2. Berijazah SD/MI

$34,71 \%$

3. Berijazah SMP/MTs

$15,47 \%$

4. Berijazah SMA/MA

$11.20 \%$

1 BPS, Statistik. Kesejabteraan Rakyat, (Jakarta: BPS, 2003), hal. 142-143. 
5. Berijazah SMK/MAK

6. Berijazah Diploma I/II

7. Berijazah Akademi/Diploma III

8. Universitas/Diploma IV

9. $\mathrm{S} 2 / \mathrm{S} 3$
$3,00 \%$

$0,88 \%$

$0,56 \%$

$1,87 \%$

$0,10 \%$

Selain angka-angka tersebut di atas indikator lain yang juga menunjukkan keterkaitan dengan kualitas SDM Provinsi Kalsel ke depan adalah mutu lulusan SLTP dan SLTA. Berdasarkan hasil kajian Badan Pertimbangan Pendidikan Daerah (BPPD) Provinsi Kalsel (2003) mutu lulusan SLTP (SMP/MTs.) dan SLTA (SMA/SMK/MA) tergolong masih rendah (rata-rata dengan predikat $\mathrm{C}$ ). Mutu lulusan SLTP dan SLTA ini dianalisis berdasarkan hasil NEM/UAN 2 tahun berturut-turut (2001/2002 dan 2002/2003).

\subsection{Sektor Kesehatan}

Derajat kesehatan penduduk juga dipakai menjadi tolak ukur kemajuan pembangunan SDM, yang terdiri dari: Angka Kematian Bayi (AKB), Angka Kematian Ibu (AKI), Usia Harapan Hidup (UHH), Perbaikan Gizi dan Perbaikan Lingkungan.

Sampai dengan tahun 2001 yang lalu indikator kemajuan pembangunan kesehatan berdasarkan data Dinas Kesehatan Provinsi Kalsel tahun 2004 menunjukkan angka-angka sebagai berikut:

a. Angka Kematian Bayi (AKB) 45 per 1000 kelahiran. Angka ini masih lebih tinggi dari AKB Nasional 35 per 1000 kelahiran hidup.

b. Angka Kematian Ibu (AKI) 126 per 1000 kelahiran hidup. Angka ini lebih tinggi dari AKI Nasional 101 per 1000 kelahiran hidup.

c. Usia Harapan Hidup (UHH) 62,2 tahun. Angka ini masih di bawah ratarata UHH Nasional 65 tahun pada tahun 2004.

d. Untuk perbaikan gizi anak balita memperlihatkan hasil yang nyata. Untuk gizi kurang 18,04\% (masih di bawah 20\%) dan gizi buruk 3,05\% (di bawah 5\%).

e. Konsumsi protein sudah cukup (melebihi $50 \mathrm{gr} /$ orang/hari). Sedangkan angka kecukupan gizi untuk konsumsi energi masih di bawah standar (2,150 kalori/orang/hari).

f. Rumah tangga yang menggunakan ledeng (air bersih) sebagai sumber air minum mengalami peningkatan dari 34,34\% pada tahun 1999 menjadi $55,50 \%$ pada tahun 2004. Namun dari segi pemerataan masih didominasi oleh rumah tangga di kota-kota. 


\subsection{PDRB dan Daya Beli Masyarakat}

\subsubsection{PDRB}

Produk Domestik Regional Bruto (PDRB) Kalimantan Selatan menurut lapangan usaha atas dasar harga berlaku dengan migas tahun 2004 mencapai Rp. 24.503.864,00 dan tanpa migas Rp. 23.921.731,00. Sedangkan atas dasar harga konstan (1999) mencapai Rp. 7.556.649,00 dan tanpa migas Rp. 7.467.417,00.

Menurut data BAPPEDA Kalimantan Selatan (2005), laju pertumbuhan ekonomi tahun 2004 dengan migas 5,09\% dan tanpa migas juga tercatat 5,09\%. Selanjutnya dilihat dari kontribusi persektor, sektor pertanian masih memberikan andil terbesar dalam pembentukan PDRB. Kemudian disusul sektor pertambangan dan penggalian serta sektor industri pengolahan seperti nampak pada tabel berikut ini:

\section{Tabel 1}

\section{Distribusi Prosentasi Produk Domestik Regional Bruto} Menurut Lapangan Usaha atas Dasar Harga Berlaku 2002, 2003, 2004

\begin{tabular}{|c|l|c|c|c|}
\hline No & \multicolumn{1}{|c|}{ Lapangan Usaha } & 2002 & 2003 & 2004 \\
\hline$(1)$ & \multicolumn{1}{|c|}{$(2)$} & $(3)$ & $(4)$ & $(5)$ \\
\hline 01 & Pertanian & 24,12 & 23,40 & 23,71 \\
\hline 02 & Pertambangan dan penggalian & 17,39 & 17,05 & 17,43 \\
\hline 03 & Industri pengolahan & 17,09 & 16,48 & 15,93 \\
\hline 04 & Listrik, gas, dan air bersih & 0,94 & 0,93 & 0,93 \\
\hline 05 & Bangunan & 4,60 & 4,62 & 4,64 \\
\hline 06 & Perdagangan, restoran dan perhotelan & 15,47 & 15,16 & 14,94 \\
\hline 07 & Pengangkutan dan komunikasi & 8,65 & 8,88 & 9,05 \\
\hline 08 & Keuangan, persewaan dan jasa perusahaan & 3,05 & 4,04 & 4,03 \\
\hline 09 & Jasa-jasa & 8,69 & 8,92 & 9,19 \\
\hline \multicolumn{2}{|c|}{ PDRB Dengan Migas } & 100,00 & 100,00 & 100,00 \\
\hline & PDRB Tanpa Migas & 97,39 & 97,61 & 97,62 \\
\hline
\end{tabular}

Sumber: BPS Kalsel, 2005. 
Tabel 2

\section{Distribusi Prosentasi Produk Domestik Bruto Menurut Lapangan Usaha atas Dasar Harga Konstan 1993 Tahun 2002, 2003, 2004}

\begin{tabular}{|c|l|c|c|c|}
\hline No & \multicolumn{1}{|c|}{ Lapangan Usaha } & 2002 & 2003 & 2004 \\
\hline$(1)$ & \multicolumn{1}{|c|}{$(2)$} & $(3)$ & $(4)$ & $(5)$ \\
\hline 01 & Pertanian & 22,51 & 22,56 & 22,54 \\
\hline 02 & Pertambangan dan penggalian & 18,18 & 17,97 & 18,29 \\
\hline 03 & Industri pengolahan & 15,16 & 14,63 & 14,16 \\
\hline 04 & Listrik, gas, dan air bersih & 1,70 & 1,64 & 1,60 \\
\hline 05 & Bangunan & 4,50 & 4,66 & 4,68 \\
\hline 06 & Perdagangan, restoran dan perhotelan & 15,04 & 14,83 & 14,67 \\
\hline 07 & Pengangkutan dan komunikasi & 10,89 & 11,12 & 11,36 \\
\hline 08 & Keuangan, persewaan dan jasa perusahaan & 3,15 & 3,77 & 3,79 \\
\hline 09 & Jasa-jasa & 8,87 & 8,83 & 8,91 \\
\hline \multicolumn{2}{|c|}{ PDRB Dengan Migas } & 100,00 & 100,00 & 100,00 \\
\hline \multicolumn{2}{|c|}{ PDRB Tanpa Migas } & 98,71 & 98,82 & 98,82 \\
\hline
\end{tabular}

Sumber: BPS Kalsel, 2005.

PDRB menurut penggunaan untuk tahun 2004 memperlihatkan komposisi penggunaan barang dan jasa yang digunakan untuk konsumsi akhir, baik yang dihasilkan di wilayah sendiri maupun yang berasal dari wilayah lain. Penggunaan untuk konsumsi rumah tangga masih dominan dengan menyerap sekitar $43,33 \%$ dari total PDRB dengan rincian pengeluaran untuk makanan sebesar $28,63 \%$ dan non makanan sebesar $14,7 \%$.

Sedangkan pengeluaran untuk pembentukan modal tetap bruto (PMTB) hanya sebesar 15,04\%. Bila diketahui PDRB per kapita tahun 2004 sebesar Rp 6.581.282,00 per tahun, dan pengeluaran untuk konsumsi 43,33\%, berarti Rp 2.851.669,00. Sisanya digunakan untuk pendidikan anak, belanja barang non konsumsi, rekening-ekening rumah tangga, perawatan kesehatan, dan cadangan (tabungan).

\subsubsection{Daya Beli Masyarakat}

Daya beli masyarakat dipengaruhi oleh kenaikan pendapatan masyarakat itu sendiri dibandingkan dengan kenaikan harga-harga kebutuhan (barang dan jasa). Jika kenaikan pendapatan masyarakat lebih tinggi dari kenaikan harga barang dan jasa maka dikatakan daya beli masyarakat tinggi, sebaliknya jika kenaikan pendapatan masyarakat lebih rendah dari kenaikan barang dan 
jasa, maka dikatakan daya beli masyarakat turun.

Salah satu pendekatan untuk mengukur pendapatan masyarakat adalah PDB (Produk Domestik Bruto) untuk tingkat nasional dan PDRB (Produk Domestik Regional Bruto) untuk tingkat daerah. Dan untuk keperluan analisis daya beli masyarakat, PDRB yang dipakai adalah PDRB per kapita. Sedangkan untuk kenaikan harga barang dan jasa dapat dilihat dari kenaikan Indeks Harga Konsumen (IHK) atau lebih dikenal dengan istilah inflasi.

Perkembangan daya beli masyarakat Kalimantan Selatan dilihat dari PDRB per kapita dan laju inflasi dalam satu dasawarsa terakhir adalah sebagaimana terlihat pada tabel berikut ini:

\section{Tabel 3}

\section{Perkembangan Daya Beli Masyarakat Kalimantan Selatan}

\begin{tabular}{|c|c|c|c|}
\hline Tahun & $\begin{array}{c}\text { Pertumbuhan } \\
\text { PDRB Per-Kapita }\end{array}$ & Tingkat Inflasi & Daya Beli \\
\hline$(1)$ & $(2)$ & $(3)$ & $(4)$ \\
\hline 1994 & 17,29 & 5,87 & + \\
\hline 1995 & 15,11 & 4,2 & + \\
\hline 1996 & 13,84 & 5,71 & - \\
\hline 1997 & 8,24 & 12,98 & + \\
\hline 1998 & 49,05 & 74,43 & - \\
\hline 1999 & 16,68 & 1,47 & + \\
\hline 2000 & 6,65 & 7,54 & + \\
\hline 2001 & 12,52 & 8,36 & - \\
\hline 2002 & 10,23 & 9,18 & 6,77 \\
\hline 2003 & 6,72 & & \\
\hline
\end{tabular}

Sumber: BPS Kalsel 2005

Dari tabel di atas terlihat sebelum krisis ekonomi 1997 daya beli masyarakat terus meningkat. Pada tahun 1997 saat terjadinya krisis ekonomi daya beli masyarakat menurun. Penurunan paling tajam terjadi pada tahun 1998. Setelah itu daya beli masyarakat mengalami fluktuasi.

\section{Kondisi Ideal}

Kondisi ideal adalah kondisi yang paling diharapkan oleh semua bangsa. Kondisi ideal ini berada pada posisi mendekati nilai maksimum indikator Indeks Pembangunan Manusia (IPM) atau Human Development Indext (HDI). Indikator IPM (HDI) tersebut terdiri dari angka harapan hidup, angka melek huruf, rata-rata 
lama sekolah, dan pengeluaran (konsumsi) per kapita. Indikator tersebut sebagaimana terlihat pada tabel berikut ini:

\section{Tabel 4}

\section{Nilai Maksimum dan Minimum Indikator IPM (HDI)}

\begin{tabular}{|c|l|c|c|c|}
\hline No. & \multicolumn{1}{|c|}{$\begin{array}{c}\text { Indikator IPM (HDI) } \\
\text { IPM [ =x(i)] }\end{array}$} & $\begin{array}{c}\text { Nilai } \\
\text { Maksimum }\end{array}$ & $\begin{array}{c}\text { Nilai } \\
\text { Minimum }\end{array}$ & Catatan \\
\hline$(1)$ & \multicolumn{1}{|c|}{$(2)$} & $(3)$ & $(4)$ & $(5)$ \\
\hline 01 & Angka Harapan Hidup & 85 & 25 & $\begin{array}{c}\text { Sesuai Standar Global } \\
\text { (UNDP) }\end{array}$ \\
\hline 02 & Angka melek huruf & 100 & 0 & $\begin{array}{c}\text { Sesuai Standar Global } \\
\text { (UNDP) }\end{array}$ \\
\hline 03 & Rata-rata lama sekolah & 15 & 0 & $\begin{array}{c}\text { Sesuai Standar Global } \\
\text { (UNDP) }\end{array}$ \\
\hline 04 & $\begin{array}{l}\text { Pengeluaran (konsumsi) per } \\
\text { kapita }\end{array}$ & 13.327 .196 & 400 & $\begin{array}{c}\text { Sesuai Standar Global } \\
\text { (UNDP) }\end{array}$ \\
\hline
\end{tabular}

Sumber: BPS Kab. Tanah Laut, 2000.

\section{B. Pembahasan}

\section{Tujuan Pembangunan SDM}

Tujuan pembangunan sumberdaya manusia (SDM) pada dasarnya adalah untuk mewujudkan SDM yang beriman dan bertakwa, berakhlak mulia, sehat, berilmu, kreatif, bertanggung jawab, dan mampu mewujudkan kesejahteraan bagi diri dan keluarganya, serta secara bersama-sama mewujudkan kemakmuran bagi bangsa dan negaranya. Sumberdaya manusia yang dimaksudkan di sini adalah penduduk yang siap, mau dan mampu memberikan sumbangan terhadap usaha pencapaian tujuan organisasi (the people who are ready, willing and able to contribute to organizational goal). ${ }^{2}$

Dalam istilah lain konsep SDM ini dapat disejajarkan dengan tenaga kerja (man power) yang meliputi angkatan kerja dan bukan angkatan kerja. Potensi yang digunakan oleh seorang pekerja untuk bekerja bermacam-macam. Ada yang menggunakan energi kekuatan fisik saja dengan keterampilan yang sederhana, ada yang mengandalkan kemampuan teknologi, dan ada pula yang menggunakan kemampuan berpikir mengendalikan SDM itu sendiri, sumber daya alam (SDA) dan sumber daya buatan (SDB).

2 Taliziduhu Noraha, Teori Pembangunan Sumber Daya Manusia (Rineka Cipta, Jakarta, 1994), hal. 7. 
Dengan demikian pembangunan SDM itu benar-benar diarahkan agar manusia itu dapat menjadi khalifah di muka bumi dengan tugas memakmurkan bumi, sebagaimana firman Allah berikut ini:

"Ingatlah ketika Tuhanmu berfirman kepada malaikat; sesungguhnya Aku hendak menjadikan khalifah di bumi”. Mereka berkata: "Mengapa Engkau hendak menjadikan khalifah di bumi itu orang yang akan menumpahkan darah, padahal kami senantiasa bertasbih dengan memuji Engkau dan menyucikan Engkau". Tuhan berfirman; "Sesungguhnya Aku mengetahui apa-apa yang tidak kamu ketahui" (Q.S. al-Baqarah; 30).

\section{Manfaat Pembangunan SDM}

Dengan kemampuan masing-masing SDM memberikan kontribusi bagi pembangunan baik untuk dirinya sendiri, maupun secara bersama-sama untuk pembangunan bangsa dan negaranya. Pembangunan SDM menurut United Nation Development Program (UNDP) bermanfaat untuk meningkatkan horison pandangan seseorang. Seorang manusia yang telah berkembang akan meningkatkan pandangannya menjadi lebih luas sehingga ia dapat mengadakan pilihan-pilihan bahkan menyodorkan berbagai pilihan untuk sesamanya. ${ }^{3}$

Dengan demikian, pembangunan SDM itu adalah tindakan memilih yang terbaik di antara yang baik untuk dilaksanakan dalam rangka meningkatkan kualitas hidup yang bermuara pada kesejahteraan masing-masing individu beserta keluarga dan secara bersama-sama untuk kemakmuran bangsa dan negaranya. Manusia yang dapat memilih adalah manusia yang dapat berpikir, dapat membedakan yang baik dan yang buruk, yang bermoral dan tidak bermoral, dan tahu hak dan kewajibannya.

\section{Daya Saing}

Daya saing atau sering pula disebut Indeks Pembangunan Manusia (IPM) yang merupakan terjemahan dari Human Development Indext (HDI) adalah kelebihan atau keunggulan yang dimiliki oleh seseorang atau suatu bangsa dibandingkan dengan seseorang atau bangsa lain, yang biasa disebut dengan istilah competitif

3 H.A.A. Tilaar, Beberapa Agenda Reformasi Pendidikan Nasional, (Jakarta: Tera Indonesia, 1999), hal. 54.

4 Saleh Safraji, Seminar Pembangunan Ekonomi, (Surabaya: Untag, 2002). 
advantage. ${ }^{4}$ Daya saing inilah yang menentukan peringkat keberhasilan suatu negara atau daerah dalam membangun ekonomi negara atau daerah dan kesejahteraan masyarakatnya. Daya saing ini adalah hasil dari proses pembangunan SDM yang dimotori oleh tiga sektor utama, yaitu pendidikan, kesehatan, dan ekonomi (PDRB dan daya beli masyarakat) dan sektor-sektor lainnya yang menunjang.

Sebagai ilustrasi dapat dilihat dari laporan hasil penelitian $\mathrm{UNDP}^{5}$ berikut ini: IPM (HDI) Indonesia di tingkat dunia:

1. Tahun 1998 menempati peringkat 109 dari 174 negara

2. Tahun 2001 menempati peringkat 102 dari 162 negara

3. Tahun 2002 menempati peringkat 110 dari 162 negara

4. Tahun 2003 menempati peringkat 112 dari 175 negara

IPM (HDI) ASEAN 1998 dalam peringkat dunia:

1. Singapura menempati peringkat 28

2. Brunai Darussalam peringkat 35

3. Thailand menempati peringkat 59

4. Malaysia menempati peringkat 60

5. Indonesia menempati peringkat 109

IPM (HDI) negara maju tahun 2003:

1. Kanada menempati peringkat 1

2. Amerika Serikat menempati peringkat 4

3. Jepang menempati peringkat 8

Korelasi positif antara daya saing dengan kemakmuran orang per orang atau suatu bangsa secara keseluruhan dapat dilihat pada angka IPM (HDI) tersebut dan kenyataan empirik di lapangan, seperti Kanada, Amerika Serikat, Jepang, Singapura dan Brunai Darussalam adalah negara-negara yang penduduknya sejahtera secara materi dan bangsa yang makmur.

\section{Kesejahteraan}

Kesejahteraan adalah tujuan dari pembangunan SDM dan pembangunan negara secara keseluruhan. Kesejahteraan dalam perspektif ekonomi dipahami sebagai terjadinya keseimbangan antara kebutuhan hidup manusia dengan dapatnya

5 Dinas Kesehatan Prop. Kalsel (Makalah Seminar Pembangunan Kesejahteraan Masyarakat, 2004).

6 M. Ma'ruf Abdullah, Membangun Kinerja BMT-LKM Syari'ah dan Kesejabteraan Nasabah Dalam Perspektif Negara Kesejahteraan, (Banjarmasin: Antasari Press, 2008), hal. 95. 
menyediakan barang dan jasa yang dijadikan pemuas kebutuhan hidup manusia itu.

Terwujudnya kesejahteraan rakyat melalui terbangunnya negara kejahteraan (welfare-state) merupakan bentuk riil dari angan-angan (cita-cita) founding fathers Republik Indonesia ini, baik Soekarno, Hatta, Syahrir, dan lain-lain yang mencitacitakan sebuah negara yang berkeadilan sosial yang melindungi warga negaranya, khususnya mereka yang miskin dan lemah. ${ }^{6}$

Pengalaman empirik negara-negara Eropa (negara-negara yang tergolong maju) dalam membangun negara kesejahteraan ini dapat disimak dari pernyataan Fererra berikut ini:

"Negara kesejahteraan merupakan pencapaian terakhir dari abad ke dua puluh. Program-programnya telah memberikan wadah kelembagaan bagi ide-ide mulia masyarakat Eropa modern, yaitu kebebasan, kesetaraan dan solidaritas, serta memberikan kontribusi dan kesempatan hidup seluruh warga negara, khususnya orang miskin. Negara kesejahteraan Eropa bisa menjadi model bagi kawasan lain di dunia, serta menunjukkan kepada mereka bahwa perpaduan yang saling menguntungkan antara pertumbuhan dan kohesi sosial, serta antara mekanisme pasar dan perlindungan sosial, serta antara penghargaan terhadap pencapaian individu dan pemberi bantuan kepada mereka yang membutuhkan" (Fererra dalam Triwibowo, 2006) ${ }^{7}$

Apa yang dikemukakan oleh Fererra ini akan semakin meyakinkan kita apabila kita memperhatikan dengan cermat peringkat dekomodifikasi atau kesejahteraan yang dapat dicapai oleh negara-negara OECD (Organization for Economic Cooperation and Development) seperti nampak pada tabel berikut ini:

7 Triwibowo dkk, Mimpi Negara Kesejabteraan, (Jakarta: LP3ES, 2006). 


\section{Tabel 5}

\section{Peringkat Dekomodifikasi (Kesejahteraan) Negara-Negara Anggota OECD}

\begin{tabular}{|c|l|c|}
\hline No. & \multicolumn{1}{|c|}{ Nama Negara } & Nilai Dekomodifikasi (Kesejahteraan) \\
\hline$(1)$ & \multicolumn{1}{|c|}{$(2)$} & $(3)$ \\
\hline 1 & Belanda & 13,0 \\
\hline 2 & Denmark & 13,8 \\
\hline 3 & Norwegia & 17,1 \\
\hline 4 & Swedia & 22,0 \\
\hline 5 & Australia & 23,3 \\
\hline 6 & Amerika Serikat & 23,4 \\
\hline 7 & Selandia Baru & 24,1 \\
\hline 8 & Kanada & 27,1 \\
\hline 9 & Irlandia & 27,5 \\
\hline 10 & Inggris & 27,7 \\
\hline 11 & Italia & 29,2 \\
\hline 12 & Jepang & 29,8 \\
\hline 13 & Perancis & 31,1 \\
\hline 14 & Jerman & 32,4 \\
\hline 15 & Finlandia & 32,4 \\
\hline 16 & Swiss & 38,1 \\
\hline 17 & Austria & 38,3 \\
\hline 18 & Belgia & 39,1 \\
\hline \multicolumn{2}{|c|}{ Rata-rata } & 27,2 \\
\hline
\end{tabular}

Sumber: Erping Anderson (1990), Triwibowo (2006) dalam Abdullah, 2008, hal. 96.

Untuk mewujudkan negara kesejahteraan ini oleh negara-negara maju seperti OECD diterapkan adanya sistem kesejahteraan sebagai hak sosial warga negara dan harus pula diimbangi oleh dua hal yang saling terkait, yaitu pertumbuhan ekonomi dan kesempatan kerja (full employment). Jadi ada strategi segi tiga antara peran negara dalam pertumbuhan ekonomi - jaminan hak sosial - kebijakan aktif tenaga kerja, yang merupakan karakteristik kunci dari suatu negara kesejahteraan. ${ }^{8}$

Dalam konteks negara kesejahteraan ini Indonesia berada di posisi mana? Inilah barangkali pertanyaan yang terlupakan oleh para penentu kebijakan di tanah air. 
Kalau kita mau jujur ada baiknya kita melihat cakupan skema jaminan sosial di kawasan Asia Timur di Asia Tenggara, serta cakupan skema jaminan sosial di Indonesia sendiri sebagaimana terlihat dalam tabel-tabel berikut ini:

\section{Tabel 6}

\section{Cakupan Skema Jaminan Sosial di Asia Timur dan Asia Tenggara}

\begin{tabular}{|c|l|c|c|c|c|c|c|}
\hline No & \multicolumn{1}{|c|}{ Negara } & $\begin{array}{c}\text { Kecelakaaan } \\
\text { Kerja }\end{array}$ & Kesehatan & Pensiunan & $\begin{array}{c}\text { Pengang- } \\
\text { guran }\end{array}$ & $\begin{array}{c}\text { Tunjangan } \\
\text { Keluarga }\end{array}$ & $\begin{array}{c}\text { Pengeluaran } \\
\text { sosial } \mathrm{x})\end{array}$ \\
\hline$(1)$ & $(2)$ & $(3)$ & $(4)$ & $(5)$ & $(6)$ & $(7)$ & $(8)$ \\
\hline 1 & Jepang & $\sqrt{ }$ & $\sqrt{ }$ & $\sqrt{ }$ & $\sqrt{ }$ & $\sqrt{ }$ & 14,1 \\
\hline 2 & Korea Selatan & $\sqrt{ }$ & $\sqrt{ }$ & $\sqrt{ }$ &. &. & 5,6 \\
\hline 3 & Taiwan & $\sqrt{ }$ & $\sqrt{ }$ & $\sqrt{ }$ & $\sqrt{ }$ &. & 11,1 \\
\hline 4 & Singapura & $\sqrt{ }$ & $\sqrt{ }$ & $\sqrt{ }$ &. &. & 3,3 \\
\hline 5 & Indonesia & $\sqrt{ }$ & $\sqrt{ }$ & $\sqrt{ }$ &. &. & 1,7 \\
\hline 6 & Malaysia & $\sqrt{ }$ & $\sqrt{ }$ & $\sqrt{ }$ &. & & 2,9 \\
\hline 7 & Thailand & $\sqrt{ }$ & $\sqrt{ }$ & $\sqrt{ }$ & $\sqrt{ }$ & $\sqrt{ }$ & 1,9 \\
\hline
\end{tabular}

Sumber : Triwibowo, 2006 dalam Abdullah, 2008; hal. 98

\section{Tabel 7}

\section{Cakupan Skema Jaminan Sosial di Indonesia}

\begin{tabular}{|c|l|c|c|}
\hline No. & \multicolumn{1}{|c|}{ Jenis Jaminan } & $\begin{array}{c}\text { \% populasi yang } \\
\text { tercakup/menerima }\end{array}$ & $\begin{array}{c}\text { \% populasi yang tak } \\
\text { tercakup/tidak menerima }\end{array}$ \\
\hline$(1)$ & \multicolumn{1}{|c|}{$(2)$} & $(3)$ & $(4)$ \\
\hline 1 & $\begin{array}{l}\text { Pensiunan/tunjangan hari } \\
\text { tua }\end{array}$ & 7 & 93 \\
\hline 2 & Tunjangan pengangguran & 0 & 100 \\
\hline 3 & Jaminan kesehatan & 15 & 85 \\
\hline
\end{tabular}

Sumber: Triwibowo, 2006 dalam Abdullah, 2008; hal. 98

Dari 2 (dua) tabel tersebut jelas sekali Indonesia dalam hal mengembangkan kesejahteraan bagi rakyatnya masih jauh tertinggal dari negara-negara lain. Dengan demikian berarti pula cita-cita founding fathers untuk mewujudkan kesejahteraan rakyat Indonesia ketika mendirikan republik ini masih memerlukan waktu yang panjang.

Dalam skope nasional dengan posisi IPM (HDI) kita berada pada peringkat 112 dari 175 negara (2003) hanya bisa menghasilkan kesejahteraan yang masih jauh tertinggal dari negara-negara di Asia Timur dan Tenggara, sebagaimana 
tergambar dalam tabel 6 dan 7, dan lebih-lebih lagi bila dibandingkan dengan negaranegara OECD (Organization for Economic Co-operation and Development) sebagaimana tergambar dalam tabel 5 .

\section{IPM (HDI) Kalimantan Selatan}

Fokus tulisan ini adalah untuk mengetahui IPM (HDI) Kalimantan Selatan dan dampaknya terhadap kesejahteraan rakyat. Untuk itu dapat kita lakukan langkah-langkah sebagai berikut:

5.1. Menetapkan indikator-indikator IPM (HDI) sebagai berikut:

5.1.1. Angka harapan hidup

5.1.2. Melek huruf

5.1.3. Rata-rata lama sekolah

5.1.4. Pengeluaran (konsumsi) per-kapita

5.2. Menetapkan rumus perhitungan sebagai berikut:

5.2.1.

$$
\mathrm{IPM}=1 / 3[\mathrm{x}(1)+\mathrm{x}(2)+\mathrm{x}(3)]
$$

Di mana :

$\mathrm{x}(1)$ : Indeks harapan hidup

$\mathrm{x}(2)$ : Indeks pendidikan $=2 / 3$ (indeks melek huruf) $+1 / 3$ (indeks rata-rata lama sekolah)

$\mathrm{x}(3)$ : Indeks standar hidup layak

5.2.2. Indeks $x(i)=[x(i)-x(i) \min ] /[x(i) \operatorname{maks}-x$ (i) min $]$

Di mana :

x (i) : Indikator ke-1 $(1,2,3)$

$\mathrm{x}$ (i) maks : nilai maksimum $\mathrm{x}$ (i)

$\mathrm{x}$ (i) min : nilai minimum $\mathrm{x}$ (i)

5.2.3. Hasil pengukuran (perhitungan) dapat diringkas sebagai berikut:

5.2.3.1 Angka usia harapan hidup (UHH) rata-rata 61,3

5.2.3.2 Melek huruf 93,2\%

5.2.3.3. Rata-rata lama sekolah 7,0 tahun

5.2.3.4. Pengeluaran (konsumsi) per-kapita Rp. 596.200,-

Pengukuran tersebut menghasilkan IPM (HDI) Kalimantan Selatan dengan skor 64,30 dan berada pada peringkat 23 dari 30 Provinsi di Indonesia. ${ }^{9}$

$9 \quad$ BPS, 2004. 


\section{Analisis Kesejahteraan}

Hasil pengukuran (perhitungan) IPM (HDI) ini kalau kita sandingkan dengan nilai maksimum indikator IPM (HDI) pada tabel 4 kolom (3), maka untuk:

1. Angka harapan hidup kesenjangannya 23,7

2. Angka melek huruf kesenjangannya 6,8

3. Rata-rata lama sekolah kesenjangannya 8

4. Pengeluaran (konsumsi per-kapita) kesenjangannya 12.730.996.

Angka-angka skor komponen yang membentuk IPM Kalimantan Selatan tersebut apabila dicermati atau diruntut ke belakang, jelas sekali datanya berkorelasi.

Indikator pendidikan di Kalimantan Selatan sebagaimana disebutkan di halaman 3 menunjukkan persentasi penduduk yang memiliki ijazah/STTB tertinggi sampai dengan jenjang pendidikan menengah (SMA/MA) ke atas termasuk Provinsi-Provinsi yang kurang dari 25\%, kecuali DKI Jakarta (44,92\%), Daerah Istimewa Yogyakarta (32,64\%), Kalimantan Timur (28,14\%), Sulawesi Utara (26,06\%) dan Riau (26,05\%).

Kondisi ini menunjukkan indikator kualitas pendidikan formal semakin tinggi ijazah/STTB yang dimiliki rata-rata penduduk mencerminkan taraf intelektualitas suatu bangsa ${ }^{10}$ dan intelektualitas juga berkorelasi dengan taraf hidupnya suatu bangsa. Makin tinggi taraf hidup seseorang maka kesejahteraannya juga makin tinggi.

Indikator kesehatan di Provinsi Kalimantan Selatan yang terdiri dari angka kematian bayi, angka kematian ibu, usia harapan hidup, perbaikan gizi, konsumsi protein, dan penggunaan air bersih masih di bawah rata-rata nasional. Data ini menunjukkan rata-rata kualitas kesehatan penduduk Kalimantan Selatan masih di bawah rata-rata nasional. Dengan demikian kontribusi indikator kesehatan terhadap kesejahteraan juga belum maksimal.

Bila kita perhatikan pula indikator ekonomi khususnya penggunaan PDRB sebagaimana dijelaskan di atas (dalam penjelasan tabel 2) dapat diketahui bahwa sebagian terbesar PDRB tersedot untuk konsumsi rumah tangga, yaitu sebesar 43,33\%, pendidikan anak 15\%, belanja barang nonkonsumsi 10\%, rekening rumah tangga 4,5\%, perawatan kesehatan 3\%, cadangan (tabungan) 4,13\%. Sedangkan untuk pembentukan modal tetap bruto hanya 15,04\%, maka berarti modal yang digunakan untuk meningkatkan PDRB pada tahun berikutnya relatif kecil. Dan itu berarti peningkatan PDRB ke depan juga kecil. 
Dengan demikian, persentasi yang dapat digunakan untuk kesejahteraan rakyat juga kecil. Memperhatikan besarnya angka untuk konsumsi rumah tangga (43,33\%), ini mengindikasikan secara rata-rata penduduk Kalimantan Selatan masih banyak yang tergolong miskin. Dengan demikian tiga indikator yang membentuk IPM tersebut berkorelasi positif dengan IPM Kalimantan Selatan dengan skor 64,30 atau berada pada peringkat 23 dari 30 Provinsi.

Ke depannya kondisi ini harus dirubah/diupayakan perbaikannya dengan program yang komprehensif dan realisasi yang nyata. Kalau tidak kita akan selamanya dalam posisi terpuruk, sebagaimana firman Allah:

"Sesungguhnya Allah tidak akan mengubah nasib sesuatu kaum sehingga mereka mengubah keadaan yang ada pada diri mereka sendiri”. (Q.S. ar-Ra'ad: 11).

Program-program yang komprehensif dan perlu direalisasikan sehubungan dengan kondisi IPM Kalimantan Selatan tersebut masing-masing:

6.1 Sektor Pendidikan:

a) Meningkatkan program wajib belajar 9 tahun menjadi wajib belajar 12 tahun (sampai tingkat SMA/MA).

b) Melengkapi fasilitas, sarana, dan prasarana pendidikan.

c) Merealisasikan anggaran pendidikan 20\% dari APBD Provinsi dengan APBD Kabupaten/Kota.

d) Melengkapi guru pada sekolah-sekolah yang masih kekurangan guru.

e) Meningkatkan kualifikasi dan profesionalisme guru.

6.2 Sektor Kesehatan:

a) Menghidupkan kembali dan mengaktifkan kegiatan PUSYANDU.

b) Memperbaiki dan meningkatkan gizi anak balita dan anak sekolah, terutama TK dan SD dengan menghidupkan kembali program PTMAS (Program Tambahan Makanan bergizi untuk Anak Sekolah).

c) Meningkatkan penyuluhan kesehatan masyarakat dan gerakan hidup sehat.

d) Memperluas jangkauan penggunaan air bersih (PAM).

e) Meningkatkan pemberantasan berbagai macam penyakit menular.

6.3 Sektor Ekonomi (PDRB dan daya beli masyarakat)

a) Melaksanakan pembangunan ekonomi dengan program padat karya.

b) Menumbuhklan dan memperbanyak usaha mikro, kecil, dan menengah 
dengan memberikan pinjaman modal dengan bunga/jasa pinjaman yang rendah.

c) Mendayagunakan sektor informal (kaki lima) sebagai penyangga ekonomi rakyat kecil.

d) Mengembangkan dan meningkatkan program pelatihan kewirausahaan.

e) Melindungi industri dalam negeri, termasuk industri rumah tangga.

\section{Penutup}

Dari uraian di atas dapat disimpulkan pembangunan sumberdaya manusia di Provinsi Kalimantan Selatan adalah sesuatu yang sangat penting mengingat hasil analisis IPM menempatkan Provinsi Kalimantan Selatan pada urutan ke 23 dari 30 Provinsi di Indonesia (BPS, 2004).

Pembangunan sumberdaya manusia di Provinsi Kalimantan Selatan perlu dipersiapkan dengan perencanaan yang komprehensif, dan didukung oleh data dan informasi yang akurat, dilaksanakan yang sungguh-sungguh, konsisten, dan berkesinambungan sehingga pada tahap pertama dapat merubah peringkat IPM Kalimantan Selatan dari peringkat ke 23 menjadi peringkat yang lebih kecil urutannya dan secara bertahap dapat memperbaiki kesejahteraan masyarakat. Skor IPM menunjukkan semakin kecil angka IPM semakin makmur suatu negara/daerah, dan semakin sejahtera rakyatnya. Sebaliknya semakin besar angka IPM, semakin tertinggal suatu negara/daerah dari kemakmuran, dan semakin tidak sejahtera rakyatnya.

\section{DAFTAR PUSTAKA}

Abdullah, M. Ma'ruf. 2008. Membangun Kinerja BMT (LKM Syari'ab) dan Kesejabteraan Nasabah (Dalam Perspektif Negara Kesejabteraan). Banjarmasin: Antasari Press.

BAPPEDA Kalsel. 2005. Laporan Pembangunan Daerah Kalimantan Selatan.

BPPD Prop Kalsel. 2003. Kajian Pendabuluan tentang Mutu Lulusan SLTP dan SLTA di Provinsi Kalsel.

BPS Kab. Tanah Laut. 2000. Analisis Situasi Pembangunan Manusia Kab. Tanah Laut.

BPS Kalsel. 2005. Kalimantan Selatan dalam Figur 
BPS. 2003. Statistik Kesejabteraan Rakyat.

Dinas Kesehatan. 2005. Laporan Kesehatan Prop. Kalsel.

Dinas Pendidikan. 2005. Laporan Pendidikan Prop. Kalsel.

Taliziduhu, Ndraha. 1994. Pengantar Teori Pembangunan Sumber Daya Manusia. Jakarta: Rineka Cipta.

Pierson, C. 2004. Later Industrialiation and Development of Welfare State. UNRISA.

Saleh, Safradji. 2001. Seminar Pembangunan Ekonomi. Surabaya: Untag.

Tilaar, H.A.A. 1999. Beberapa Agenda Reformasi Pendidikan Nasional. Jakarta: Terra Indonesia.

Triwibowo dkk. 2006. Mimpi Negara Kesejabteraan. Jakarta: LP3ES. 